\title{
Flourishing workplaces: a multisensory approach to design and POE
}

Article

Accepted Version

Clements-Croome, D., Pallaris, K. and Turner, B. (2019) Flourishing workplaces: a multisensory approach to design and POE. Intelligent Buildings International Journal, 11 (3-4). pp. 131-144. ISSN 1750-8975 doi:

https://doi.org/10.1080/17508975.2019.1569491 Available at https://centaur.reading.ac.uk/81552/

It is advisable to refer to the publisher's version if you intend to cite from the work. See Guidance on citing.

To link to this article DOI: http://dx.doi.org/10.1080/17508975.2019.1569491

Publisher: Taylor \& Francis

All outputs in CentAUR are protected by Intellectual Property Rights law, including copyright law. Copyright and IPR is retained by the creators or other copyright holders. Terms and conditions for use of this material are defined in the End User Agreement.

\section{www.reading.ac.uk/centaur}

\section{CentAUR}

Central Archive at the University of Reading 
Reading's research outputs online 


\title{
Flourishing Workplaces: A Multisensory Approach to Design and POE
}

Derek Clements-Croome

School of the Built Environment, University Reading

d.j.clements-croome@reading.ac.uk

Kay Pallaris

Mapping Futures Ltd.

kay.pallaris@gmail.com

Briony Turner

Institute for Environmental Analytics, University of Reading

b.d.turner@the-iea.org

\begin{abstract}
How can we design workplaces which occupants thrive in, which are functional but are also expressive? Drawing on research about the senses and office related studies this paper demonstrates how buildings can be designed to allow for positive multi-sensory experiences. In order to design a creative and productive workplace, it is essential to consider how the environment is making us feel, behave and act within it. As the workplace continues to evolve, the case is made for a sensory palette framework to drive a systems approach to building environmental design enabling the integration of the multi-modal sensory relationship of people's reactions within various environmental settings. Technological advances, in the form of wearables that monitor our physiological and stress responses offer the opportunity to capture empirical data, further enabling the investigation to see how a diverse range of environmental settings affect our physical, mental and social wellbeing. The paper goes on to develop the established conceptual theories of 'Flourish' proposing a move beyond comfort when designing the interiors and the mechanics of facility controls towards a sensory impacts framework that considers a whole life costing approach using the Flourish Model sets the basis for a design and post-occupancy evaluation toolkit.
\end{abstract}

Purpose: To model a way of making health and wellbeing a primary aim at the initial and POE stages of design

Design/methodology/approach: Using the results of research and practice via social surveys and physiological measurements.

Findings: Built environment affects people physically, mentally and socially.

Practical implications: Use as an early design tool to identify strengths and weaknesses in the given project intentions and to use as a post-occupancy evaluation tool based on subjective and objective environmental factors; feelings of satisfaction, mood and happiness; economic value factors like absenteeism and staff retention.

Originality/value: New approach using flourish rather than comfort as a health and wellbeing indicator. 


\section{Keywords}

Workplace Design, Multisensory, Flourish Model, Health, Wellbeing.

\section{Disciplines presented in the paper:}

Environmental psychology

Architectural engineering

Planning and design

\section{INTRODUCTION}

In order to design a creative and productive workplace, it is essential to consider how the environment is making us feel, behave and act within it. Here the paper draws on the study of the senses to demonstrate how important it is to consider our sensory experience of the designed environment. It goes on to summarise an evolving body of research that is starting to account for non-optimised design in terms of health life years lost (e.g. Shrubsole et al. 2015) and presents empirical studies that reveal the impact of poorly designed workplaces (e.g. British Council for Offices-BCO-studies 2012; 2014; 2016;2017;2018), making links between the research and the applied design thinking. It further develops the established conceptual theories of 'Flourish' and 'Wellbeing' (Huppert and So 2013;Barrett and Zhang, 2012; Kim and de Dear, 2012 ; Seligman, 2011 ; Diener and Biswas-Diener, 2008 ; Maslow,1943). The Flourish model is described in Clements-Croome (2018) and earlier viewpoints presented in the Green Building Council publications (World Green Council -WGBC- 2014 on offices- see page 31 Viewpoint on flourishing environments), UK Green Building Council -UKGBC- 2016 on homes- see page 14 on Flourish, UKGBC 2016 Report on Retail, proposing a move beyond comfort towards a more comprehensive understanding of how sensory change from stimuli around the office can help improve productivity Clements-Croome (2018), BCO (2017), BCO (2018).

\section{MAKING SENSE OF THE MULTI-SENSORY EXPERIENCE}

To design spaces that benefit our wellbeing requires knowledge of how the body responds to the multiple stimuli it receives from the environment. The nature of the stimuli that is designed, be it the design and/or placement of objects (desks, chairs) in a space, the physical form of the building and internal layout, opportunities for social interaction together with the workplace culture all interact to create a multi-sensory experience. An understanding of how we sense the environment stems from the study of the senses.

It is now commonly believed that we experience more than the five commonly known senses of vision, hearing, touch, taste, and smell (Craig, 2002 ; Craig, 2009 ; Macpherson, 2010 ; Haverkamp, 2012 ; Henshaw, 2012 ; Matthen, 2012 ; Stokes et al., 2014 , Shultz, 2015 , among others. Table 3.1 sets out the additional sensory modalities defined within, what represents just a small sample of research from philosophy, bio-physiology and more recently from neuroscience data. The brain does not perceive environmental stimuli in isolation instead sensory receptors process the signals and then relay these to the brain each interacting and converging, resulting in the perceptions, emotions and experiences we feel and respond to. Each sense provides only a 
partial perspective on a complex whole that is only perceptible through the coordinated processing of multiple senses (O’Callahan, 2016).

Table 1 Summary understanding of our sensory modalities

The two senses of proprioception and interoception tell us what the internal body itself is doing and as such, allow an individual to evaluate their personal physical state in response to stimuli. Proprioception refers to the sense of joint position and movement that are essential for maintaining posture and coordinating movement. Simply explained, interoception is the sense of organ function giving rise to the conscious perceptions of bodily processes such as hunger and heart-beat (Schulz, 2015). Interoception has come to refer to the multi-modal integration of sensory channels resulting in one's complete perception of their personal physiological condition (Craig, 2002; Craig, 2009; Ceunen et al., 2016).

Interoception is contemporarily defined as the sense of the internal state of the body. It encompasses the brain's process of integrating signals relayed from the body into specific subregions - like the brainstem, thalamus, insula, somatosensory, and anterior cingulate cortex - allowing for a nuanced representation of the physiological state of the body. This is important for maintaining homeostaticconditions in the body and, potentially, aiding in selfawareness.(Wikipedia January 2019)

In effect, interoception can be thought of not just the sense of the physiological condition of the body but also, as the 'sense of wellbeing' that is necessary for the generation of both the motivation and attention necessary to influence behavioural decisions regarding survival and quality of life (Craig, 2002). Recent knowledge suggests that interoception is not restricted to mere sensations, but relies upon learned associations, memories and emotions which together give rise to the subjective representation of the body state (Ceunen et al., 2016).

Insights into the functioning of the sensory systems provide vital clues for how we should design the built environment so that it is as responsive to our basic human needs as the natural world it has replaced. The architect, Juhani Pallassma, in his publication The Eyes of the Skin (2012) challenges the dominance of the visual sense, asserting that the senses can be regarded as extensions of the sense of touch because the senses as a whole define the interface between the skin our largest sense organ and the world. The skin generally reads the texture, weight, density and temperature of our surroundings. The combination of sight, sound and touch allows the person to get a scale of space, distance or solidity. He stipulates that design dominated by the visual sense has given rise to " $a$ cultural condition and environment that generates alienation, abstraction and distance instead of promoting the positive experiences of belonging, rootedness and intimacy" (Pallasmaa, 2011, p. 51).

Drawing on product optimisation design, a multi-sensory design approach termed 'synesthetic design' offers an alternative to traditional visual sensory bias by providing the systematic incorporation all five senses. The aim of synesthetic design is "to coordinate all sensations stimulated by an object in a manner that results in a pleasant, harmonious overall appearance while coinciding with the particular function(s) desired" (Haverkamp, 2012, p. 14). The term itself is derived from Greek, 'syn' indicates together and 'aisthesis', sensation. Unlike conventional 
design, it enables cross-sensory correlations and design strategy that caters for a systematic approach that optimises correlations between the senses.

\section{EMPIRICAL STUDIES ON WORKPLACE DESIGN}

The 2014 British Council for Offices survey of 2000 UK office workers showed that one in four believed their work environment did not support their physical wellbeing (BCO, 2014). Dissatisfied respondents were particularly unhappy with a lack of colour (80\%), a lack of greenery (64\%) and a lack of art (61\%) in their workplaces (BCO, 2015). On a global scale, the Human Spaces Survey (Cooper and Browning, 2015) found that 58\% of 7,600 office workers in 16 countries (of which $85 \%$ of offices surveyed were located in an urban environment) did not report having plants in the office and $47 \%$ reported no natural light. Just under half (47\%) reported having felt stressed in their workplace within the last three months and $28 \%$ of respondents reported that they did not have a quiet space to work in their office. The five elements most desired in the office revealed by the survey (see Table 2) were inherently linked to nature and the sensory experience of the workplace.

Table 2 The sensory appeal of the five elements most wanted in the office

\subsection{Sensory Considerations when designing for Workplace Concentration}

High productivity requires high and sustained levels of concentration. Many personal health and social factors can affect this including: low self-esteem, low morale, an inefficient work organisation, poor social relations. External environmental distractions such as excessive heat or noise can further exacerbate one's interceptive condition, physically manifested as lethargy, headaches and physical ailments, all of which feature in surveys carried out on building sickness syndrome (Clements-Croome, 2011). Additionally with the advent of emails, texts, messaging applications and the increasing prevalence of a networked, online mentality, concentration disruptors are no longer limited to the physical surrounding environment.

It is possible to alter the opportunity for heightened attention through several design factors. Colour is one approach; the Human Spaces (Cooper and Browning, 2015) study identified the colours blue, green, yellow and white as office colours having a significant impact on workers' productivity. In the Kajima building in Tokyo aroma fragrances are used to condition the air. This research shows that aromas can help people feel a sense of freshness to offset fatigue enabling employees to concentrate (Takenoya, 2006).

Designing for acoustic refuge should also be key in a workplace. Quiet can also heighten personal creativity as the space is providing an individual with opportunities to collate ideas and assimilate thoughts.

\subsection{Sensory Considerations when designing for Workplace Interaction}

Spatial experiments by geographers at the University of Sheffield found a strong relationship between ambient sound and the readiness of participants to engage in communication with strangers. Their research showed that before participants could feel secure enough to reveal 
personal characteristics and to be receptive to having their preconceptions 'unsettled', the design of the spaces in which encounters take place have to promote emotional security. Factors like the size and configuration of space, the relationship between primary and secondary space, the acoustics, issues of ownership, and surveillance all contributed to generating meaningful encounters (Mayblin et al., 2015). Furthermore, bad acoustics reduced the willingness of participants to form smaller groups or paired bonds but increased the likelihood of collaboration with a wider group (as well as shouting across the space). Spaces that echoed less (in their example due to lower ceilings and soft flooring) reduced reverberation which, in turn, resulted in increased one-to-one interaction and an improved sense of security. Through other experiments, they were able to verify Rodaway's hypothesis that "auditory perception involves the whole body whilst at the same time giving the immediate impression of sensing from a particular point or dedicated organ [...]" (Rodaway, 1994, p. 91). This, whilst a discrete experiment, suggests questioning of the appropriateness and perhaps indicates that further research is required when applying open plan design in workplaces which are dependent upon strong inter-personal relations for collaborative working.

\subsection{Sensory Considerations when designing for enhanced creativity}

Natural elements are often associated with perceived wellbeing: light, natural materials, views of nature and sound of water all create a sense of calm helping to increase attention. 'The 14 Patterns of Biophilic Design' offers a powerful tool that can be used by built environment professionals for interiors and exteriors (Browning et al., 2014) to reconnect the human sensory systems to the biophysical reality and the meaning that these natural elements conjure up. For instance, the rustling of leaves, the fragrance of flowers, birdsong, the sound of flowing water, the spaciousness of landscapes (particularly horizons between earth, sky and water), a light breeze and fresh, cool, clean air are all details that are remembered in terms of the emotional response they provoke. A walk outside in nature has the ability to calm and soothe and refocus the mind, by restimulating and rebalancing our sensory receptors. A walk outside in nature can therefore promote creativity. In the UK, there is growing interest in how green infrastructure can be integrated into buildings and used indoors as a building service, not just as a biophilic service to contribute to improving the health, wellbeing and productivity of employees but also to simultaneously improve the energy efficiency of office buildings and enhance the resilience of the internal microclimates of buildings to a changing climate (Dover, 2015).

\section{BEYOND ENVIRONMENTAL COMFORT}

The word 'comfort' is perhaps overused. It has a neutral but long term durable quality. It is usually seen as a pleasant or relaxed state of a human being in relation to their environment but surely that is only part of what we need for the concentrating mind. Is one highly attentive when comfortable or is there a danger of being bored, losing attention or even falling asleep? Cabanac (2006) writes about pleasure and joy and their role in human life, and indicates how transients are important in providing variety and contrast for the human sensory system to respond to. During the day we hope for and seek joyful moments perhaps a tree in blossom, pleasant air movement or changing light patterns. There is an echo of this in Maslow's book Religions, Values and Peak Experiences in 1964 when he writes about peak experiences which can be transitory, momentary or longer term but trigger happiness and uplift in mood. Cabanac introduced the term alliesthesia which means a 
stimulus may give rise to a pleasant or unpleasant sensation depending on the internal state of the person (de Dear 2011). Our experience of the environment is the result of an interplay of heat, light, sound and many other factors. Buildings should provide a multi-sensory experience. The senses need stimulation to react to otherwise boredom sets in.

Malnar and Vodvarka (2004) comment: The problem with most of the research on the thermal environment is that it has centred on thermal comfort or thermal neutrality. They go to quote other work. Wilson (1984) states: As with the auditory area of research, the approaches concentrate on preventing feelings of discomfort, rather than producing positive responses--such as interesting, invigorating - to thermal conditions.

Langdon (1973) commended a new way of thinking about thermal comfort by replacing a passive model with an active one in which a self-regulatory system has an open-ended interaction with the physical environment in forms governed by social constraints.

Well-being is a more comprehensive term than comfort. Ong (2013) presents a set of essays entitled Beyond Environmental Comfort, which stretch the meaning of comfort into new directions. Vink (2012) in his editorial relating to comfort of products like chairs and cars for example calls for a new model for comfort based on the work of De Looze et al (2003) which is applicable to the built environment field.

The impact of the environment on people is difficult to predict because the environment has an effect which is more than the sum of its parts (de Dear 2004; Bluyssen 2014). Another complication is that sensory modalities interact. Bluyssen (2014) reviews the literature on interactions between noise and heat; noise and lighting; air quality and thermal comfort.

This interactive characteristic is also evident when we compare our reactions in say a black and then a white room. The same sized room can make one feel 'closed in' or 'more open'. Then do the same comparison with low (feel more closed in) and high (feel more spacious) height rooms. Feelings can be affected by colour or room size in these two simplified examples but then the environment is a complex array of stimuli so measuring the overall reaction of people to it is complex. How does architecture influence our moods, thoughts and health? Lehrer (2011) reviews research that shows some unexpected links between various design factors like colour and room height for example with various aspects of work performance.

Gou et al (2014) has carried research on the gap between comfortable and stimulating illuminance settings. Levels of 400 - 500lux were felt to be neutral and comfortable whereas some periods with levels above 900 lux were perceived as more stimulating for the task being undertaken. Perhaps this indicates that comfort is a backdrop which needs to be non-distracting but human beings also need sensory change from the stimuli around them brought about through the work task, the people and the built environment. It is a complex balance that needs to be achieved.

Barrett et al $(2010,2012)$ believes that there is no real understanding of the holistic impacts of built spaces on people despite the huge amounts of knowledge there is on individual aspects like heat, light and sound. The outcome of his HEAD ( Holistic Evidence and Design) project is the SIN Model which has three main dimensions - Stimulation level; Individualisation; Naturalness.

Stimulation arises from the amount of information in the setting in which triggers like colour, aromas, greenery, or things that are changing such as formal or informal social contacts or changes in the natural setting give variety, context and interest. An example of a building designed to be 
enjoyable and uplifting is the atrium in the Kajima office in Tokyo described by Takenoya (2006) in which aroma and bio-music are used intermittently to provide variety and stimulation. Complexity, colour and texture for example give contrast and make the environment more interesting. Over stimulation can give confusing and hectic signals which can increase stress levels whereas too little stimulation can be boring (Bluyssen 2014).

Individualisation is the occupants' personal environment and includes factors like personal control, flexibility and ones identity with a space. Naturalness is the basic environmental setting and this where the comfort backdrop forms an important foundation. The holistic experience is the interplay between these three dimensions of stimulation; individualisation and naturalness.

Kano (1984) proposed a model of product and service satisfaction in the 1980s which defines three essential attributes:

- Threshold Attributes: customers expect these as a fundamental set of requirements (comfort criteria)

- Performance Attributes: though not absolutely necessary they increase customers enjoyment

- $\quad$ Excitement Attributes: these provide the extra sense of surprise and enjoyment (bonus factors)

These are a dynamic interactive set of attributes.

Kim and de Dear (2012) adapted these and described Kanos' classification in terms of basic factors; bonus factors and proportional factors. From their survey of 351 different office buildings they identified basic and proportional factors as:

- $\quad$ Basic factors: levels of temperature and sound; amount of space; visual privacy; flexible furniture; colours and textures; workplace cleanliness. These are minimal requirements.

- $\quad$ Proportional factors: air quality; light; visual comfort; sound privacy; ease of interaction; comfort of furniture; cleanliness; building maintenance. Satisfaction increased linearly as these elements improved.

- Bonus factors: colour, social climate, greenery, views, changing daylight, air movement.

These factors act like triggers that can impact mood and add pleasure to one's experience. Other factors could be aesthetics and décor.

One can see a connection here with the thinking behind the SIN model as the Stimulating element corresponds to the Bonus factor in the Kano model; Naturalness corresponds to the Basic factors; Individualisation corresponds to the Proportional factors and includes personal control.

The aim of the EU PERFECTION project was to help enable the application of new building design and technologies that improve the impact of the indoor built environment on health, comfort and feeling of safety and positive stimulation (Desmyter et al 2010; Bluyssen 2014). Desmyter (2010) suggested some indicators of positive stimulation which are similar to the response triggers proposed above. 


\section{CREATIVITY IS PART OF FLOURISHING}

Carson (2010) argues for seven brain sets to maximise imagination, productivity and innovation. These cover absorption or engagement by being open to ideas; envision using imagination; connect by divergent thinking to generate multiple solutions; reason with logic; evaluate by critically reviewing evidence, ideas and concepts; remembering that creativity can spring from negativity and streaming thoughts to allow a harmonious systemic flow of ideas.

Research in management and leadership describe conditions for stimulating creativity and these include facilitating collaboration; having a vision; delegating responsibility; showing how a company cares for employees; letting people arrange their workspace; fostering brain storming sessions in and outside the workplace.

Among all these factors one can see that creativity is part of human flourishing and needs a physical, mental and social climate to do this.

In his book The Origin of Creativity 2017 the eminent scientist E O Wilson simply says we enrich our knowledge by allowing the sciences and humanities to intermix in our endeavours. This is exactly what the Flourish model does by bringing together objective and subjective measures when designing or managing workplaces within an organization by using methodologies from the natural and social sciences. Now we can survey people's feelings about their work environment but can measure how their body is responding to that environment too so identifying the total state of being of an individual at a particular time and place.

\section{MEANING OF FLOURISHING}

Flourishing refers to the experience of life going well. It is a combination of feeling good and functioning effectively. Flourishing is synonymous with a high level of mental well-being and it epitomises mental health.

Huppert and So 2013

Huppert and So 2013 describe a European survey - 43,000 subjects in 23 countries — which aimed to define what is meant by flourishing and this resulted in defining 10 attributes of positive wellbeing or flourishing. These were:

competence, emotional stability, engagement, meaning, optimism, positive emotion, positive relationships, resilience, self-esteem and vitality. One can see how these factors are part of personal motivation.

Many of these attributes are described in the classic work of Maslow or Diener and Seligman.

Human performance underlying productivity has been defined as depending on motivation, ability or competence and opportunity offered by amenities and support systems. So here we can see the link between people's feelings and their work performance and how the environment in which they are located affects this. 
Vitality is about human energy and much has been written about how this can be sapped by poor atmospheres lacking good air quality, natural lighting or temperature control for example. Drab environments devoid of colour, views or greenery lead to dull unstimulating hours of work however interesting that might be.

These findings underlie the Flourish Model now described.

\section{FLOURISH MODEL}

The aim is to create an environment in which people thrive. The author has based the reasoning for this model on the work of Barrett (2012) and Kim and de Dear (2012) which goes beyond comfort and reaches out towards acquiring the ideal state of well-being as described by Maslow (1943), Seligman (2011), Diener and Biswas-Diener (2008). The model is based on three issues-the environmental factors, the perceptions and feelings people have in various environmental settings and the economic consequences of the environments created (World Green Building Council 2014, 2016).

The first is a normal layer featuring standard comfort health and safety guidelines for temperature, sound, light, ventilation (for the waking and sleeping states). Various Codes, Guides and Handbooks prescribe these.

The second layer is one which recognises that people prefer to have some degree of personal control over their environmental settings. Also there is a relationship between health and some of the factors we are dealing with in a proportional way. For example as ventilation increases from 8 1/s person to 25 1/s person illnesses decrease as the research by Fanger (1970; 2002), Wargocki and Wyon (2007), Wargocki, Seppanen and others (2007) have shown. So there is not a single number or narrow band to choose for design like temperature for example but rather an Individual or Proportional Layer in which a choice has to be made. In selecting a figure, one has to study the evidence for offices, schools, retail outlets or homes. Often the decision is made on low energy and cost but this has to be offset by the savings accrued by better health and productivity as evidenced by less absenteeism and presenteeism.

Thirdly there is the Sparkle or 'wow' layer which includes things like views on Nature, daylight, colour, décor, layout, aesthetics, green space around the building. These features are mainly nonquantifiable but important. These seemingly small factors can suddenly make one feel better in spirit---a bit like getting up in the morning and feeling a little sluggish then opening the curtains on to a beautiful sunny morning and feeling quivers of happiness. Some of the research is beginning to give some design data like for biophilic design (Browning et al, 2012) but in general it is things we should do even though these factors are 'soft' metrics and do not have numbers. We do know however facts like for example that homes with sea or country views fetch premium prices. Buildings in cities are particularly challenging but with careful creative thought they can be lovable joyful and soulful places for people to live and work.

We need to capture all three layers if we are going to provide buildings which people thrive and flourish in for living or work. Fig i and ii show the Flourish model (Clements-Croome 2016, 2018).

Figure 1 Flourish Model ( Clements-Croome 2018) 
This shows the advantages of using Flourish for various stakeholders. The interrelationship between how occupants feel in the environmental setting they occupy influences their motivation al energy to do work and make decisions (Clements-Croome 2018). Fig 2 shows how objective and subjective factors impact people's feelings and as a consequence the economics of the workplace.

Flourish echoes the check lists proposed by Dolan and Bernheimer. In his book Happiness by Design 2014 he proposes the SALIENT mnemonic:

$\begin{array}{ll}\text { S } & \text { SOUND } \\ \text { A } & \text { AIR } \\ \text { L } & \text { LIGHT } \\ \text { I } & \text { IMAGE (Look and Feel) } \\ \text { E } & \text { ERGONOMICS } \\ \mathrm{N} & \text { NATURE } \\ \mathrm{T} & \text { TINT (Colour) }\end{array}$

Bernheimer proposes in her book The Shaping of Us 2017 a BALANCED space checklist.

B Biophilia- natural materials, views and patterns

A Atmospheric-light, air quality, temperature and smell

L Layout-space quality, circulation

A Amenities-nutrition, movement, ergonomics

N Noise

C Cohesion-community, communication

E Energy-resources and waste

D Design-colour, shape.materials, proportions, detail and style

The WELL version2 rating system has 10 factors to consider for health and wellbeing.

Air
Water
Light
Nourishment
Movement
Thermal comfort
Sound
Materials
Mind
Community

These three independent approaches have many similar aspects. The evidence for Flourish is rooted in the research of Maslow; Seligman; Diener; Barrett mainly, together with evidence in Clements-Croome 2000; 2006; 2018. The aim is to go beyond comfort and achieve environments in which people thrive and this benefits creativity and productivity. Flourish forms the framework for the BCO 2018 Report on Wellness Matters. 
Using Flourish involves several steps:

- Work with client mapping needs with Flourish

- Use a sample survey of occupants using questions based on Flourish wheel in Fig 2

- Work with Human Resources on economic factors like sickness absence and staff retention rates

- Use Kansei or other multi factor decision making approaches to analyse results and to derive a predesign Flourish map using Flourish Wheel.

- At POE stage collect data from environment and people repeat analysis

- Recommend any changes

Data is derived from a questionnaire which is based on the following general factors as described in BCO 2017, 2018.

- Type of work-range of work

- Location-city/rural; Nature; accessibility

- HR data on absenteeism, staff turnover rates, medical problems

- Physical data plus facilities managers (FM )experience

- Occupants feedback

- Simple rating Scales for health/wellbeing using Flourish Wheel

- Other factors that arise in interviews with users

Figure 2 The Flourish Wheel 


\section{CONCLUSIONS}

The workplace is ever-changing and this has implications for how we should design the next generation of workplaces. The responses of the office workers in both the BCO and Human Spaces surveys suggest that even current practice and value sets are not realising the productivity potential that workplace design can yield. The roots of productivity are in health and wellbeing as these determine the energy you have to work and live.

We already have a wealth of knowledge about the sensory response of the human body. Wearable technology offers the opportunity for further enhancing our knowledge of how design decisions affect employees' physiological and psychological wellbeing, both at the individual and collective level. Such technology will have implications for the way we design, refurbish and build workplaces, placing an even greater emphasis on the human-centric, experiential perspective, a perspective embedded at the heart of a multi-sensory approach to workplace design (ClementsCroome, Aguilar and Taub, 2015).

Employers are realising that greater consideration of their staff within workplace design has multiple rewards, enabling them to provide a healthier working environment whilst simultaneously improving profitability and staff retention. Designing with this sensory approach in mind might at first encounter cost hurdles. This approach can be seen as potentially resulting in higher investment requirements with higher design fees allocated for the additional employee engagement and potentially higher investment required in elements of the office redesign.

A traditional workplace valuation approach considers costs in terms of occupancy per square footage. However, productivity is beginning to play an increasingly central role in what is considered economic value for money, thereby shifting the emphasis from employee floorspace ratios to designing productive working environments (BCO 2017). The Flourish Model offers an impacts framework against which design considerations can be assessed, and the resulting outcomes evaluated. If the workplace is not delivering the productive, enticing, healthy environment they need to undertake their work, employees will have a well-informed basis upon which to express dissatisfaction and act besides illness absenteeism can increase and staff retention rates decrease with poor environments. The workplace of the future must rapidly transition to incorporate environments conducive to our sense of wellbeing. This can only be achieved by creating workplaces that enable employees to flourish.

\section{ACKNOWLEDGMENTS}

The authors thank Dr Tong Yang for her editorial assistance.

\section{REFERENCES}

Barrett P., Barrett L., (2010), “The Potential of Positive Places: Senses, Brain and Spaces”, Intelligent Buildings International, 2, 3, 218-228.

Barrett, P., Barrett L., Zhang, Y., (2015), “Teachers' Views of their Primary School Classrooms", Intelligent Buildings International, 8, 3, 176-191. 
BCO, (2015), "Putting People First: Designing for Health and Wellbeing in the Built

Environment", Clements-Croome, D. Aguilar, A. M. and Taub, M. Published by British

Council for Offices. [Online] www.bco.org.uk.

BCO, (2012), "Making Art Work in the Workplace”, Research Report by International Art

Consultants in partnership with the British Council for Offices (www.bco.org.uk).

BCO, (2014), "Making the Business Case for Well-being”, The 2014 Well-being at Work Study (British Council for Offices; Morgan Lovell and Hatch) Available at:

http://www.bco.org.uk/Research/Publications/Making_the_Business_Case_for_Wellbeing.asp

BCO 2017 'Improving Productivity in the Workplace” Report

(http://www.bco.org.uk/Research/Publications/Improving Productivity in the Workplace.as px)

BCO 2018 'Wellness Matters'" Report

(http://www.bco.org.uk/HealthWellbeing/WellnessMatters.aspx).

Bluyssen, P.M., (2014), “The Healthy Indoor Environment: How to Assess Occupants' WellBeing in Buildings", Routledge.

Browning, W., (2012), "The Economics of Biophilia - Why designing with nature in mind makes financial sense", Terrapin Bright Green, LLC, New York.

Browning, W.D., Ryan, C.O. and Clancy, J.O. (2014), “14 Patterns of Biophilic Design”, Terrapin Bright Green, LLC, New York [Online] http://www.terrapinbrightgreen.com/wp-content/uploads/2014/04/14-Patterns-ofBiophilic-Design-Terrapin-2014e.pdf [Accessed on 27 March 2016]

Cabanac, M., (2006), "Pleasure and Joy, and Their Role in Human Life", Clements-Croome D. (Ed.) Creating the Productive Workplace, E \& FN Spon, London, pp. 40-50.

Carson, S., (2010). 'Your Creative Brain', Jossey-Bass and Harvard Health Publications(Harvard Medical School)

Clements-Croome D. J. (2011), "Chapter13 - The Interaction Between the Physical Environment and People", Abdul-Wahab, S.A. (Ed.), Sick Building Syndrome in Public Buildings and Workplaces. Springer-Verlag, Berlin, Germany, pp. 239-260.

Clements-Croome, D., (2018) Chapter 1 "Effects of the built environment on health and wellbeing", Clements-Croome, D. (Ed.), Creating the productive workplace: places to work creatively, Third Edition, Routledge, London, ISBN 9781138963344, pp.3-40.

Clements-Croome, D.J., (2016), Intelligent Liveable Buildings: Health and Well-being Perspectives, Lecture at Bath University March $4^{\text {th }}$ in School of Architecture and Civil Engineering. Www.derekcroome.com.

Cooper, C., Browning, W., (2015) Human Spaces: The Global Impact of Biophilic Design in the Workplace (http://humanspaces.com and http://humanspaces.com/global-report/keymessages/).

Craig, A.D. (2002), "How Do You Feel? Interoception: The Sense of the Physiological Condition of the Body", Nat Rev Neurosci, 3, 8, 655--666. 
Craig, A.D. (2009), "How Do You Feel - Now? The Anterior Insula and Human Awareness", Nat Rev Neurosci, 10, 1, 59--70.

De Dear, R., (2011), "Revisiting an Old Hypothesis of Human Perception: Alliesthesia", Building Research \& Information, 39, 2, 108-117.

De Looze, M.P., et al., (2003), "Sitting Comfort and Discomfort and the Relationships with Objective Measures”, Ergonomics, 46, 985--997

Desmyter, J., et al., (2010), Perfection T1.4, "A Review of Safety, Security Accessibility and Positive Stimulation Indicators”, Final Report August 30th, Available at: www.caperfection.eu/media/files/Perfection_D14_final.pdf.

Diener, E., Biswas-Diener, R., (2008), Happiness: Unlocking the Mysteries of Psychological Wealth, Malden, MA: Free Press.

Dover, J.W. (2015). Green Infrastructure: Incorporating Plans and Enhancing Biodiversity in Buildings and Urban Environments. Earthscan from Routledge, Abingdon.

Fanger, P.O, (2002), "Human Requirements in Future Air-conditioned Environments", Advances in Building Technology, 1, 29-38.

Fanger, P.O., (1970), Thermal Comfort: Analysis and Applications in Environmental Engineering, Copenhagen: Danish Technical Press;

Gou, Z., et al., (2014), "Visual Alliesthesia: The Gap between Comfortable and Stimulating Illuminance settings", Building and Environment, 82, 42-49.

Haverkamp, M. (2012), Synesthetic Design: Handbook for a Multi-Sensory Approach, Birkhäuser, Berlin, Basel.

Henshaw, J.M. (2012), A Tour of the Senses: How Your Brain Interprets the World, The Johns Hopkins University Press, Baltimore.

Huppert F.A., So T.T., (2013), "Flourishing Across Europe: Application of a New Conceptual Framework for Defining Well-Being”, Social Indicators Research, Feb; 110(3):837-861. Epub 2011 Dec 15.

Kano, N., et al., (1984), “Attractive Quality and must-be Quality”, Journal of the Japanese Society for Quality Control (in Japanese), 14, 2, 39-48.

Kim J., de Dear R., (2012), "Nonlinear Relationships between Individual IEQ Factors and Overall Workspace Satisfaction", Building and Environment, 49, 1, 33-40.

Langdon, F.J., (1973), "Human Sciences and the Environment in Buildings", Build International, 6 January-February, 106.

Lehrer, J., (2011), “Building a Thinking Room”, The Wall Street Journal, April 30 ${ }^{\text {th }}$.

Macpherson, F. (2010), The Senses: Classical and Contemporary Perspectives, Oxford University Press, Oxford.

Malnar, J M., Vodvarka, F., (2004), Sensory Design, University of Minnesota Press.

Maslow, A.H., (1943), A Theory of Human Motivation. Psychology Review, 50(4) : 370-396.

Matthen, M. (2012), The Oxford Handbook of Philosophy of Perception, Oxford University Press, Oxford. 
Mayblin, L., Valentine, G., Kossak, F. and Schneider, T. (2015) "Experimenting with Spaces of Encounter: Creative Interventions to Develop Meaningful Contact", Geoforum, 63, 67-80

O’Callaghan, C. (2016), “Objects for Multisensory Perception”, Philosophical Studies, 173, 5, 1269-1289.

Ong, B. L, (2013), Beyond Environmental Comfort, Routledge: London.

Pallasmaa, J. (2012). The Eyes of the Skin: Architecture and the Senses, $3^{\text {rd }}$ Edition ed. John Wiley \&Sons Ltd. , West Sussex, UK.

Rodaway, P. (1994). Sensuous Geographies: Body, Sense and Place, Reprint edition (4 Nov. 2011) ed. Routledge, London.

Schulz, A. (2015), “Interoception”, Wright J.D. (Ed.) International Encyclopedia of the Social and Behavioral Sciences. Elsevier, pp. 614--620.

Seligman, M., (2011), Flourish, New York: Free Press.

Shrubsole et al. (2015). "A tale of two cities: comparative impacts of CO2 reduction strategies on dwellings in London and Milton Keynes", Atmospheric Environment, 120, 100-108. DOI: 10.1016/j.atmosenv.2015.08.074

Stokes, D., Matthen, M. and Biggs, S., (eds), (2014), Perception and Its Modalities. Oxford University Press, Oxford.

Takenoya, H. (2006). "Chapter 20: Air conditioning Systems of the K I Building, Tokyo”, In Clements-Croome, D. (Ed.), Creating the Productive Workplace, Second Edition, Taylor and Francis, London and New York, pp. 334--347.

UK Green Building Council (2016), "Health and Wellbeing in Homes", see Viewpoint page 14 on Flourish, UKGBC July 2016. Available at:

https://www.ukgbc.org/sites/default/files/08453\%20UKGBC\%20Healthy\%20Homes\%20 Updated\%2015\%20Aug\%20(spreads).pdf [last access 01-12-2017].

Vink, P., (2012), "Editorial: Comfort and Discomfort Studies Demonstrate the Need for a New Model", Applied Ergonomics, 43, 271--276

Wargocki, P., (2007), "Improving Indoor Air Quality Improves the Performance of Office Work and Schoolwork", Technical University of Denmark, Kgs. Lyngby, Denmark [Online] Available at:

http://www.inive.org/members_area/medias/pdf/Inive\%5CIAQVEC2007\%5CWargocki_ 2.pdf [Accessed 10 Aug 2009]

Wargocki, P., and Wyon, P., (2007), “The Effect of Moderately Raised Classroom Temperatures and Classroom Ventilation Rate on the Performance of Schoolwork by Children", HVAC\&R Research, 13, 2, 193-220.

Wilson, F., (1984), A Graphic Survey of Perception and Behaviour for the Design Professions, New York: Van Nostrand Reinhold, p. 198.

World Green Building Council (WGBC), (2014), "Health, Wellbeing and Productivity in Offices: the Next Chapter for Green Building", World Green Building Council (info@ukgbc.org or office@wgbc.org) (see Clements-Croome Viewpoint on Beyond 
Comfort pages 31-33) Available at:

http://www.worldgbc.org/sites/default/files/compressed_WorldGBC_Health_Wellbeing _Productivity_Full_Report_Dbl_Med_Res_Feb_2015.pdf [last access 01-12-2017].

World Green Building Council (WGBC), (2016), "Health, Wellbeing \& Productivity in Retail: The Impact of Green Buildings on People and Profit", World Green Building Council (info@ukgbc.org or office@wgbc.org) led by UK Green Building Council. Available at: https://www.ukgbc.org/sites/default/files/UK-

GBC\%20Health\%20\&\%20Wellbeing\%20Retail\%20Report\%202016\%20WEB.pdf [last access 01-12-2017].

\section{FURTHER READING}

Bakker, I. (2014), "Uncovering the secrets of a productive work environment. A journey through the impact of plants and colour". Delft: Delft University of Technology. PhD thesis. See in particular chapter 9: Towards a new framework for a uniform assessment of people's experience of the built environment. I can send this chapter on request. See also www.levenswerken.eu.

Bakker, I., Van der Voordt, T., de Boon, J. \& Vink, P., (2014), "Pleasure, Arousal, Dominance: Mehrabian and Russell revisited", Current Psychology, 33, 3, 405-421. DOI 10.1007/s12144-014-9219-4 Online ISSN 1936-4733. To be downloaded from http://resolver.tudelft.nl/uuid:e53bc84e-9bd9-4e34-8be5-514384e9ec42.

Bakker, I.C., Van der Voordt, T., Vink, P. \& De Boon, J. (2013), Red or Blue meeting rooms: does it matter? The impact of colour on perceived productivity, social cohesion and wellbeing. Facilities 31(1/2), 68-83. DOI: http://dx.doi.org/10.1108/02632771311292527. To be downloaded from: http://resolver.tudelft.nl/uuid:b2ecfaee-fa26-4543-9e9dcd2093e92387.

Van der Voordt, T., Bakker. I. \& De Boon, J. (2017), "Colour preferences for four different types of spaces", Facilities, 35, 4, 155-169. DOI: http://dx.doi.org/10.1108/F-06-2015-0043. 
Table 1 Summary understanding of our sensory modalities

\begin{tabular}{|l|l|}
\hline Sensory Modalities & Sense \\
\hline Touch-Tactioception & Sense of touch through haptic system \\
\hline Visual - Ophthalmoception & Sense of vision/sight \\
\hline Auditory - Audioception & Sense of hearing / Sense of the perception of sound \\
\hline Gustatory - Gustaoception & Sense of taste \\
\hline Olfactory - Olfacception & Sense of smell via olfactory system \\
\hline Thermoreception/Themoception & Sense of temperature via themoreceptors in the skin \\
\hline Equilibrioception & $\begin{array}{l}\text { Sense of balance by the vestibular system and visual } \\
\text { cues }\end{array}$ \\
\hline Interoception & Sense of the physiological condition of the entire body \\
\hline Nociception & Sense of pain \\
\hline Proprioception & $\begin{array}{l}\text { Sense of limb/body position without visual cues: the } \\
\text { ability to perceive position, weight, and resistance of } \\
\text { objects in relation to the body }\end{array}$ \\
\hline $\begin{array}{l}\text { Kinesthesia } \\
\text { (often incorporated into proprioception) }\end{array}$ & $\begin{array}{l}\text { Sense of movement and position; the ability to sense } \\
\text { the extent, direction, or weight of body movement }\end{array}$ \\
\hline
\end{tabular}

Sources of information (Craig, 2002; Craig, 2009; Macpherson, 2010; Haverkamp, 2012; Matthen, 2012; Stokes et al., 2014; Schulz, 2015) 
Table 2 The sensory appeal of the five elements most wanted in the office

\begin{tabular}{|l|l|l|l|}
\hline \%* & $\begin{array}{l}\text { Most Desired Office } \\
\text { Element* }\end{array}$ & Sensory Design Cues \\
\hline $44 \%$ & Natural light & $\begin{array}{l}\text { - } \\
\text { Natural light having a balance of wavelengths compared to fluorescent } \\
\text { lighting, that is conducive to the functioning of our photoreceptors in the eye. } \\
\text { Contrast of light and shade aiding shape (lines and curves) perception and } \\
\text { perception of space condition. } \\
\text { Colour hue determined by light wavelength; short wavelengths make people } \\
\text { feel cool, calmer. Long wavelengths make people feel warmer and invoke } \\
\text { more rapid muscular response. }\end{array}$ \\
\hline $17 \%$ & View of the sea & $\begin{array}{l}\text { Natural landscapes providing a harmonic contemplative visual stimulus which } \\
\text { allows attention and therefore productivity to be restored. }\end{array}$ \\
\hline $15 \%$ & Bright colours & $\begin{array}{l}\text { Bright colours (in moderation) associated (especially in Feng Shui practices) } \\
\text { with higher energy, motivation and inspiration for the flow of creative ideas. }\end{array}$ \\
\hline $20 \%$ & Indoor plants & $\begin{array}{l}\text { Related to having access to natural landscapes for restorative contemplation. } \\
\text { Plants also help to improve the acoustic soundscape as they absorb, diffract } \\
\text { and reflect sound noise, depending on the room's physical properties. }\end{array}$ \\
\hline $19 \%$ & Quiet working space & $\begin{array}{l}\text { Work to improve indoor air quality (depending on plant type), thereby altering } \\
\text { the PH and oxygen levels, which impact our chemoreceptors and interoceptors } \\
\text { and therefore our bodily function. }\end{array}$ \\
\hline $\begin{array}{l}\text { Quiet spaces provide an improved acoustic environment by removing } \\
\text { distraction and vibration that impact our visual and tactile sensory systems, } \\
\text { thus enhancing concentration and attention. }\end{array}$ \\
\hline
\end{tabular}

*based on the study of 7,600 survey responses by Human Spaces (Cooper and Browning, 2015) 


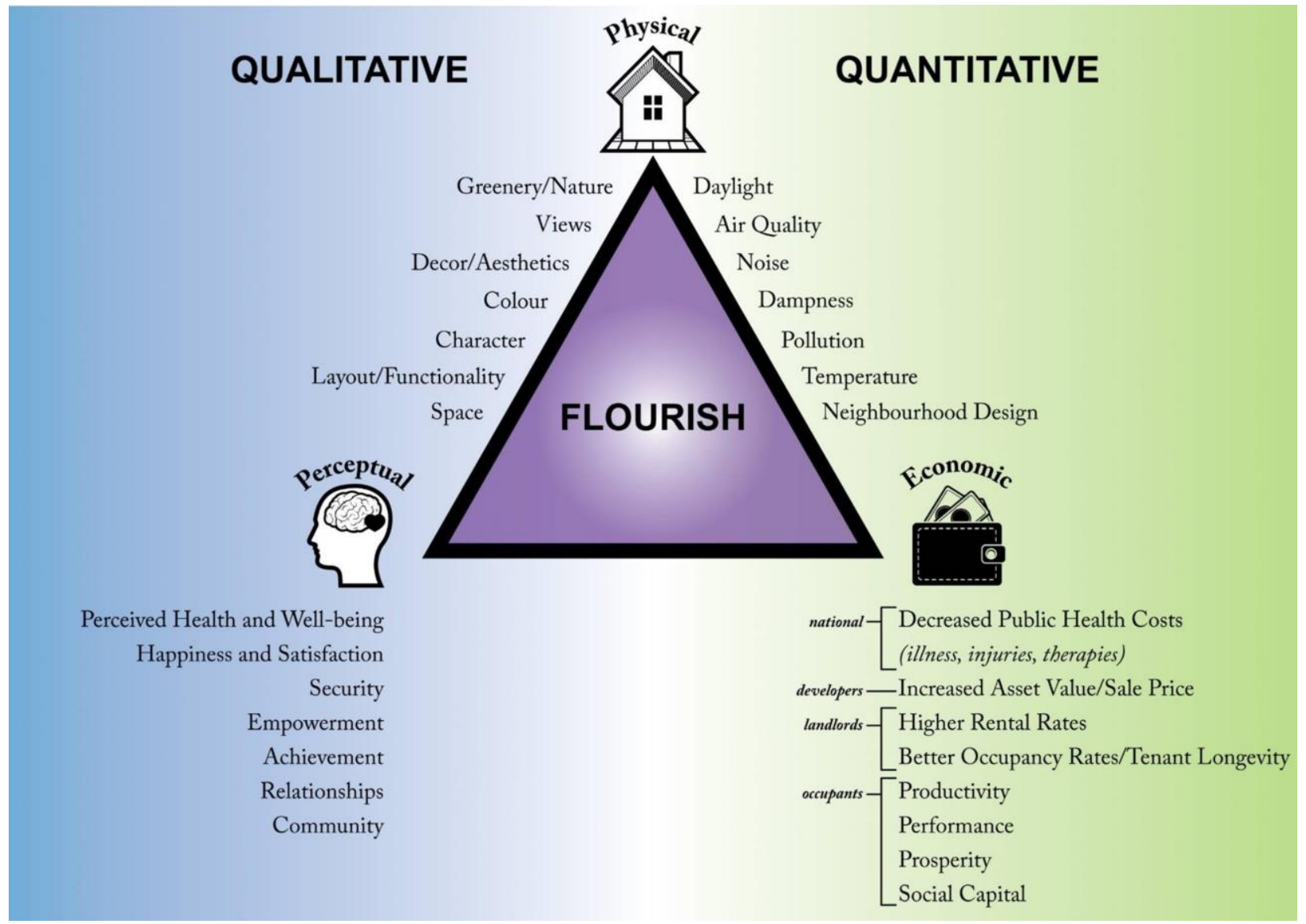

Figure 1 Flourish Model ( Clements-Croome 2018) 


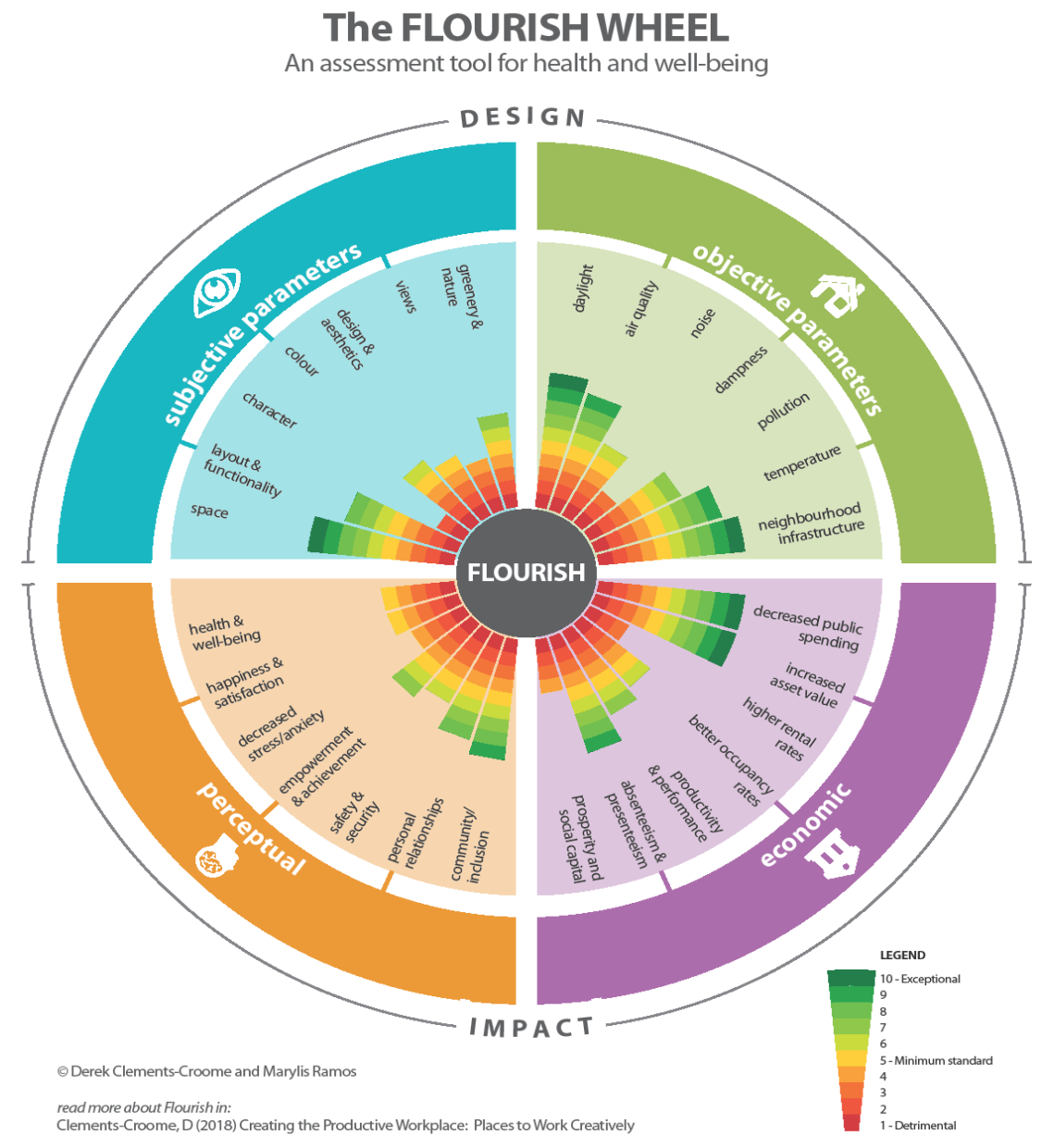

Figure 2 The Flourish Wheel 